BMJ Open

Sport \&

Exercise

Medicine

\title{
Trends in sports-related emergency department visits in the Netherlands, 2009-2018
}

\author{
Branko F Olij DD, ${ }^{1}$ Ellen Kemler, ${ }^{1}$ Huib Valkenberg, ${ }^{1}$ Christine Stam, ${ }^{1}$ \\ Vincent Gouttebarge, ${ }^{2,3}$ Evert Verhagen (iD) 2,4
}

To cite: Olij BF, Kemler E, Valkenberg $\mathrm{H}$, et al. Trends in sports-related emergency department visits in the Netherlands, 2009-2018. BMJ Open Sport \& Exercise Medicine 2020;0:e000811. doi:10.1136/ bmjsem-2020-000811

- Supplemental material is published online only. To view please visit the journal online (http://dx.doi.org/10.1136/ bmjsem-2020-000811).

Accepted 26 September 2020

\section{Check for updates}

(c) Author(s) (or their employer(s)) 2020. Re-use permitted under CC BY-NC. No commercial re-use. See rights and permissions. Published by BMJ.

${ }^{1}$ VeiligheidNL, Amsterdam, the Netherlands

${ }^{2}$ Amsterdam Collaboration on Health and Safety in Sports (ACHSS),

Amsterdam UMC, Amsterdam, the Netherlands

${ }^{3}$ Amsterdam UMC, Univ of Amsterdam, Department of Orthopaedic Surgery, Amsterdam Movement Sciences,

Meibergdreef 9, Amsterdam, the Netherlands

${ }^{4}$ Department of Public and Occupational Health, Amsterdam Movement Sciences, Amsterdam UMC, Amsterdam, the Netherlands

\section{Correspondence to}

Branko Olij;

b.olij@veiligheid.nl

\section{ABSTRACT}

Objectives We aim to describe time trends of severe sports-related emergency department (ED) visits in the Netherlands, from 2009 to 2018.

Methods Data were extracted from the Dutch Injury Surveillance System by age, gender, sports activity and injury diagnosis, from 2009 to 2018. Absolute numbers and time trends of severe sports-related ED visits were calculated.

Results Between 2009 and 2018, the overall numbers of severe sports-related ED visits in the Netherlands have significantly decreased by $14 \%(95 \% \mathrm{Cl}-19 \%$ to $-9 \%)$. This trend was seen among men $(-12 \% ; 95 \%$ $\mathrm{Cl}-18 \%$ to $-6 \%)$, women $(-19 \% ; 95 \% \mathrm{Cl}-26 \%$ to $-11 \%)$ and individuals aged $18-34$ years $(-19 \%$; $95 \%$ $\mathrm{Cl}-28 \%$ to $-10 \%)$. The number of ED visits has significantly decreased over time in soccer $(-15 \%$; $95 \% \mathrm{Cl}-24 \%$ to $-6 \%)$, ice-skating $(-80 \% ; 95 \% \mathrm{Cl}$ $-85 \%$ to $-73 \%)$ and in inline/roller skating $(-38 \%$; $95 \% \mathrm{Cl}-55 \%$ to $-15 \%)$. This was not the case in road cycle racing $(+135 \%$; $95 \% \mathrm{Cl}+85 \%$ to $+198 \%)$ and mountain bike racing $(+80 \% ; 95 \% \mathrm{Cl}+32 \%$ to $+146 \%)$. In terms of sports injury diagnoses, the number of fractured wrists $(-15 \% ; 95 \% \mathrm{Cl}-24 \%$ to $-5 \%)$, fractured hands $(-37 \% ; 95 \% \mathrm{Cl}-49 \%$ to $-21 \%)$, knee distortions (-66\%; $95 \% \mathrm{Cl}-74 \%$ to $-55 \%)$, and fractured lower legs $(-38 \% ; 95 \% \mathrm{Cl}$ $-55 \%$ to $-14 \%)$ significantly decreased over time. Conclusion Our study shows a promising reduction in the number of severe sports-related ED visits across most age groups and sports activities. As the number of $E D$ visits increased in road cycle and mountain bike racing, it is important to find out what caused these increases. Furthermore, it is essential to determine trends in exposure hours and to evaluate and implement injury prevention programmes specific for these sports activities.

\section{INTRODUCTION}

Even though maintaining a physically active lifestyle through sports has many health benefits, ${ }^{1}$ sports activities also entail a risk for injury among both the youth and adults. ${ }^{2}$ These sports injuries have a major financial impact, with an estimated annual societal cost of $€ 3$ billion in the Netherlands. ${ }^{3}$ In addition to the economic impact, sports injuries affect

\section{What are the new findings?}

The number of severe sports-related ED visits decreased considerably in the Netherlands across most age groups and sports activities between 2009 and 2018 .

- The number of ED visits increased in road cycle racing and mountain bike racing.

- The majority of the severe sports-related injury diagnoses has significantly decreased over time.

an individual's physical and psychosocial wellbeing. ${ }^{4}$ Prevention of sports-related injuries is therefore warranted.

To understand emerging sports injury trends and guide policy development aimed at preventive efforts, it is important to monitor and describe nationwide trends of sports injuries over time. ${ }^{5}$ A commonly used source used to monitor and describe nationwide sports injuries over time is emergency department (ED) visits. Studies on trends of sports-related ED visits have been performed in several countries. For example, a study performed in the USA has shown that the number of sports-related ED visits increased among children between 2001 and 2013. ${ }^{6}$ Furthermore, an Australian study has shown that the number of sports-related ED visits and hospital admissions increased among individuals aged >15 years, between 2004 and $2010 .{ }^{7}$ Both studies emphasise that additional research that monitors and describes time trends of sports-related ED visits is essential to reduce the burden of sports injuries.

In the Netherlands, many individuals with severe sports-related injuries visit the ED. However, a study describing the nationwide trends in these severe sports-related ED visits has not been performed to date. Thus, the aim of this study was to describe time trends of severe sports-related ED visits in the Netherlands, by gender, age group, sports activity and injury diagnosis, from 2009 to 2018. 


\section{METHODS}

\section{Data source}

Sports-related ED visits in the Netherlands were extracted from the Dutch Injury Surveillance System (DISS). The DISS data set is composed of a representative sample of injuries treated at 14 geographically distributed EDs in the Netherlands since $1986 .^{\circ}$ Despite the availability of the DISS data set since 1986, in the current study, data are used from 2009 until 2018. This time period was chosen as it represents the current state of affairs in the field of nationwide sports injuries, which in turn can guide current policy development, aimed at preventative efforts. The DISS data set represents 16\% of all EDs in the Netherlands and includes general and academic hospitals that provide emergency services 24 hours a day. When a patient visits one of the participating EDs, an employee of the ED (eg, a doctor or nurse) registers the basic data in an administrative system.

When the patient requires treatment for an injury, detailed information about the circumstances of the accident is recorded. In this process, it is determined whether the injury was caused while taking part in a sport, where sport is defined as physical activity which is practised within an organised or unorganised setting, such as competitive or recreational sport. ${ }^{9}$ All data on injuries that are registered by the EDs are provided anonymously to VeiligheidNL (VNL), and records are converted-by a data manager-into uniform codes and variables. In the case of open text fields, conversion is carried out by means of automatic text recognition. A random check is performed manually on the data to determine whether the data conversions were performed correctly.

Because VNL is an organisation that conducts scientific research, an appeal can be made to the exemption clause of the Medical Treatment Contracts Act (WGBO) for the use of patients' medical data for scientific research (Article 7: 458 of the Dutch Civil Code). Therefore, no explicit consent of patients was needed (Article 7: 457 of the Dutch Civil Code). Patients were informed about the existence of the surveillance system, and about the possibility to object to the inclusion of their data in the surveillance system.

The sample of 14 EDs can be extrapolated to nationwide estimates, while the age distribution, the type of hospital and other demographics are representative of all EDs in the Netherlands. ${ }^{10}{ }^{11-13}$ An extrapolation factor was calculated as follows: (No. of ED visits in the samplexNo. hospital admissions in all hospitals)/No. of hospital admission in the sample. ${ }^{14}$

\section{Severe injury}

In the Netherlands, minor injuries are often treated by a general practitioner during same-day visits. Furthermore, minor (overload) injuries are often treated at a physiotherapy centre (without a medical referral). Outside working hours, patients can be treated at a general practice centre, usually situated in a hospital. Severe injuries are often treated at an ED, which can be visited all hours of the day and is situated in a hospital. In the past 10 years, new policies have been adopted in the Netherlands aimed at improving the efficiency of emergency care. This has resulted in minor injuries being treated even more often outside EDs by the general practitioner, whereas severe injuries are still treated in the EDs. ${ }^{10}$ As minor injuries were more likely to be treated outside EDs, it was decided in the current study to only report the number of severe sports-related ED visits from the DISS data set that were treated between 2009 and 2018. It is assumed that, by doing this, a more reliable description of the incidence of sports-related ED visits in the Netherlands can be provided.

To select the severe sports-related ED visits, a derivative of the Maximum Abbreviated Injury Scale (MAIS) was used. ${ }^{15}$ The score on this scale runs from 1 (minor) to 6 (maximum) and represents the severity of the injury. ${ }^{16}$ A MAIS score was generated for the injuries in DISS by transforming 39 injury groups to corresponding categories in the International Classification of Diseases, 10th Revision. ${ }^{17}$ An overview of the MAIS classification of injury diagnoses is presented in online supplemental table S1. In the current study, severe injury is defined as one with a MAIS score of at least $2 .^{18}$

\section{Data analysis}

The absolute numbers and time trends of severe sportsrelated ED visits were specified for age, gender, sports activity and injury diagnosis for each individual year from 2009 to 2018. As the ED data were extrapolated, all absolute numbers were rounded to the nearest integer. In addition, 95\% CIs were calculated. For the calculation of time trends, absolute numbers of injuries were standardised by correcting for changes in population composition between 2009 and 2018. Standardisation was performed by direct standardisation, in which one weight was applied to all age-specific rates, irrespective of the age distribution of the population. ${ }^{19}$ Data on changes in population composition were obtained from Statistics Netherlands. ${ }^{20}$

Injuries were specified for the following age groups: $0-17,18-34,35-54$ and $\geq 55$ years. These age groups are conventional within the DISS data set. In general, the agroup $0-17$ years represents youth athletes, 18-34 years represents senior athletes, 35-54 years represents master athletes, and $\geq 55$ years represents elderly athletes.

In the DISS data set, a total of 65 sports activities are coded (online supplemental table S2). Sports activities averaging less than 500 severe sports-related ED visits a year (between 2009 and 2018) were not included in the current analyses. This cut-off was applied as the ED data were extrapolated, resulting in sports activities with less than $500 \mathrm{ED}$ visits a year being less representative for the Netherlands. Therefore, only the following sports activities were included: basketball, combat sports, field hockey, fitness, futsal, gymnastics, horse riding, iceskating, inline/roller skating, motorcycle racing, mountain bike racing, physical education, road cycle racing, 
running, skateboarding, skiing, snowboarding, soccer, swimming, tennis and volleyball.

Severe sports-related injury diagnoses identified in the EDs less than 500 times a year (between 2009 and 2018) were not included in the current study either. Again, this cut-off was applied as the ED data were extrapolated, resulting in injury diagnoses identified less than 500 times a year being less representative for the Netherlands. Therefore, only the following severe sports-related injuries were included: knee distortion (ie, a dislocation, sprain, or strain of joint and ligaments of the knee), fractured ankle, fractured collarbone/shoulder, fractured elbow, fractured foot, fractured forearm, fractured hand, fractured hip, fractured knee, fractured lower leg, fractured ribs/chest, fractured spine/spinal cord injury, fractured upper arm, fractured wrist, knee luxation, mild traumatic brain injury, muscle/tendon injury in hand/ finger, muscle/tendon injury in lower leg and severe traumatic brain injury.

To analyse the statistical significance of the trends over time, a logistic regression model was used. Both the linear and the quadratic association were tested based on standardised data, as the trend was corrected for changes in population composition between 2009 and 2018. A p value below 0.05 was considered statistically significant. The absolute percentage of the change over time and the $95 \%$ CI are reported. All analyses were performed using IBM SPSS Statistics version 25.

\section{Patient and public involvement}

This research was done without patient involvement. Patients were not invited to comment on the study design and were not consulted to develop patient-relevant outcomes or interpret the results. Patients were not invited to contribute to the writing or editing of this document for readability or accuracy.

\section{RESULTS}

\section{Gender and age group}

An overview of the absolute number of severe sportsrelated ED visits in the Netherlands from 2009 to 2018 is presented by gender and age group in table 1. Figure 1 presents the trends over time. The number of severe sports-related ED visits has significantly decreased by $14 \%$ (95\% CI $-19 \%$ to $-9 \%)$. This was also the case among men $(-12 \% ; 95 \% \mathrm{CI}-18 \%$ to $-6 \%)$ and women $(-19 \% ; 95 \%$ CI $-26 \%$ to $-11 \%)$. Even though the number of ED visits decreased for all age groups between 2009 and 2018, a significant decrease was seen only among individuals aged $18-34$ years $(-19 \%$; $95 \%$ CI $-28 \%$ to $-10 \%)$.

\section{Sports activity}

Table 2 presents the absolute number of severe sportsrelated ED visits, for the 10 sports activities with, on average, the highest number of ED visits (between 2009 and 2018). This includes soccer, physical education, horse riding, ice-skating, road cycle racing, inline/roller skating, motorcycle racing, field hockey, mountain bike racing and gymnastics. The time trends of these 10 sports activities are presented in figure 2. The number of severe sports-related ED visits has significantly decreased over time in soccer $(-15 \%$; $95 \%$ CI $-24 \%$ to $-6 \%)$, ice-skating $(-80 \% ; 95 \%$ CI $-85 \%$ to $-73 \%)$ and in inline/roller skating $(-38 \% ; 95 \%$ CI $-55 \%$ to $-15 \%)$. The number of ED visits has significantly increased over time in road cycle racing $(+135 \% ; 95 \% \mathrm{CI}+85 \%$ to $+198 \%)$ and in mountain bike racing $(+80 \% ; 95 \% \mathrm{CI}+32 \%$ to $+146 \%)$. The full data of the other 11 sports are provided in online supplemen tal table S3.

\section{Injury diagnosis}

Table 3 presents the absolute number of severe sportsrelated $\mathrm{ED}$ visits, for the 10 injuries that, on average, were diagnosed in the EDs most often (between 2009 and 2018). This includes fractured wrist, fractured collarbone/ shoulder, fractured ankle, fractured hand, knee distortion, fractured foot, fractured forearm, mild traumatic brain injury, fractured elbow and fractured lower leg. The time trends of these 10 injuries are presented in figure 3 . The injury diagnoses of fractured wrist $(-15 \% ; 95 \% \mathrm{CI}-24 \%$ to $-5 \%)$, fractured hand $(-37 \%$; $95 \% \mathrm{CI}-49 \%$ to $-21 \%)$, knee distortion (-66\%; 95\% CI $-74 \%$ to $-55 \%)$ and fractured lower leg $(-38 \%$; $95 \%$ CI $-55 \%$ to $-14 \%)$ have significantly decreased between 2009 and 2018. The full data of the other 11 injuries are provided in online supplemental table S4.

\section{DISCUSSION}

The current study described time trends of severe sportsrelated ED visits in the Netherlands between 2009 and 2018. In this time period, the number of ED visits has decreased considerably (absolute reduction of 14\%; 95\% CI $-19 \%$ to $-9 \%$ ).

\section{Comparison with other studies}

To date, a study describing the nationwide trends of severe sports-related ED visits has not been performed in the Netherlands. In contrast, previous studies have investigated time trends of sports-related ED visits in other countries. Namely, an Australian study reported an increase in sports injury-related ED visits between 2012 and 2015. ${ }^{21}$ Furthermore, an American study on sports-related ED visits among individuals aged 5-18 years reported an increase in sports-related injuries between 2009 and $2013,{ }^{6}$ whereas we found a decrease among individuals aged 0-17 years between 2009 and 2018. This difference could be explained by the fact that in the current study only severe sports-related ED visits are included. Similar to the promising reduction in ED visits reported in our study, a Swedish study reported a decrease in sports injury-related ED visits between 2004 and 2007. ${ }^{22}$ However, an Australian study reported a significant annual increase in sport-related major trauma between 2001 and 2007. ${ }^{23}$ Differences between these studies could be explained due to differences in time periods, healthcare systems and healthcare policy. 


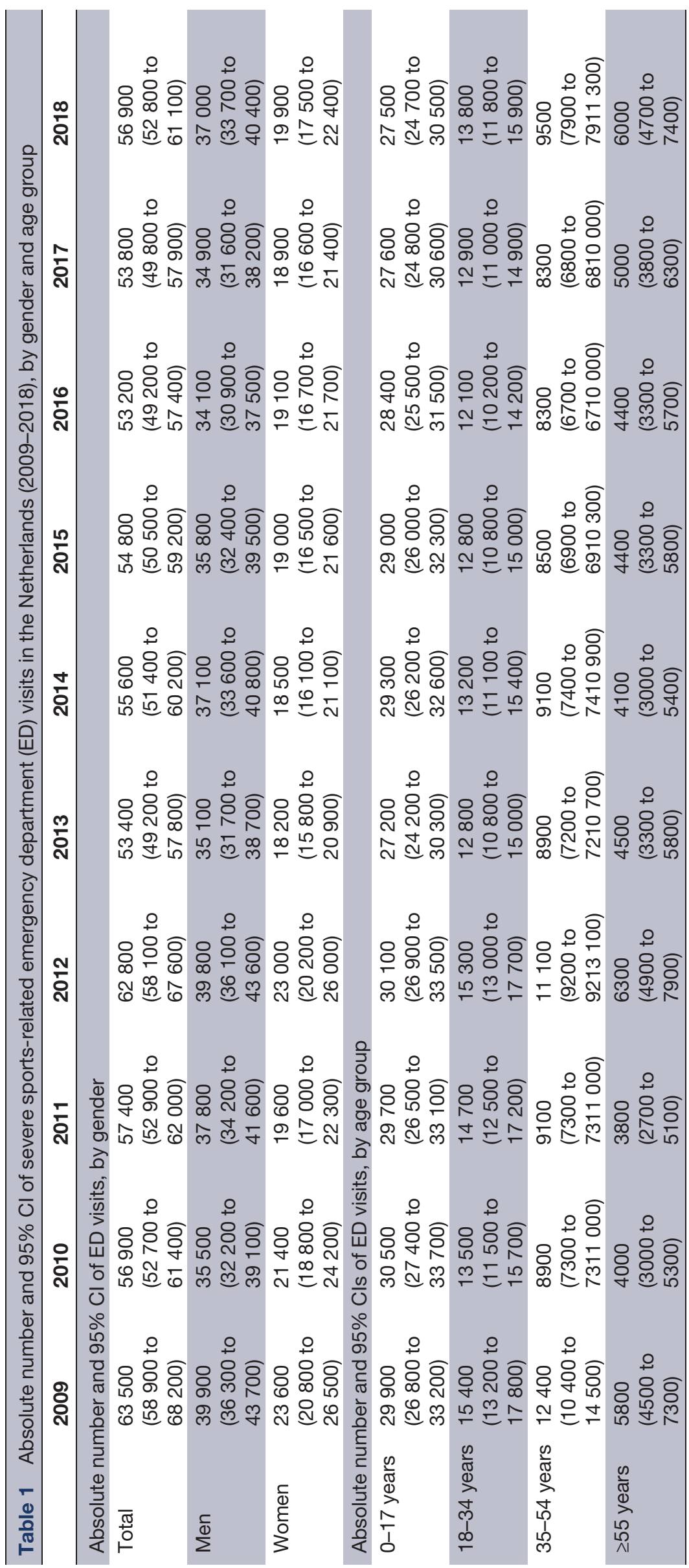



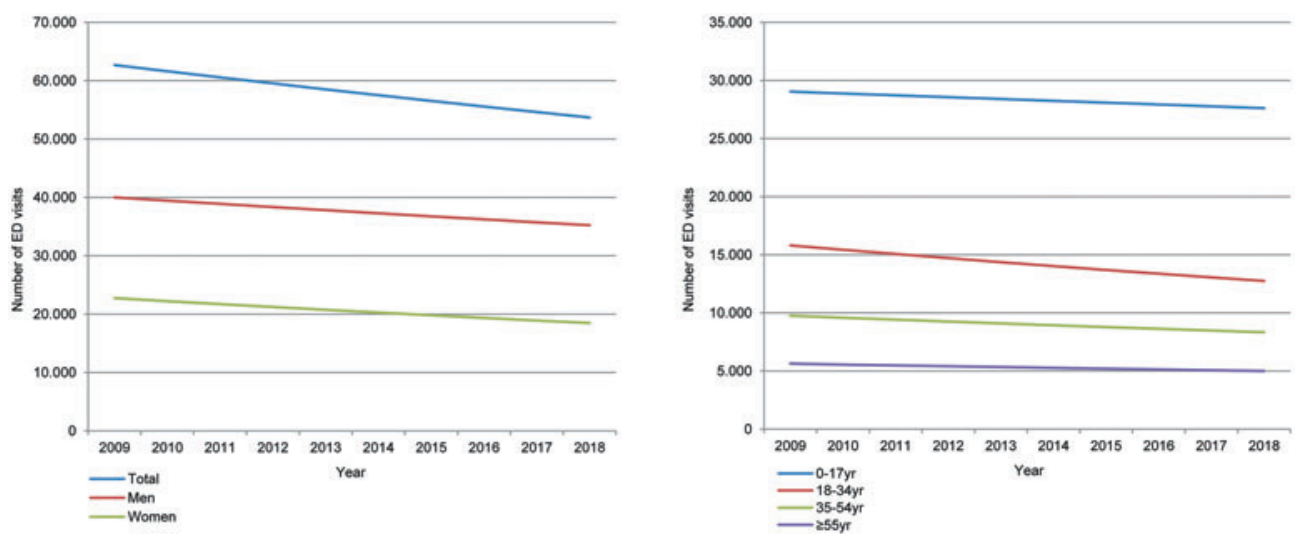

Figure 1 Time trends of severe sports-related emergency department visits in the Netherlands (2009-2018), by gender and age group.

\begin{tabular}{|c|c|c|c|c|c|c|c|c|c|c|}
\hline & 2009 & 2010 & 2011 & 2012 & 2013 & 2014 & 2015 & 2016 & 2017 & 2018 \\
\hline Soccer & $\begin{array}{l}17800 \\
(15400 \text { to } \\
20400)\end{array}$ & $\begin{array}{l}16900 \\
(14600 \text { to } \\
19400)\end{array}$ & $\begin{array}{l}18300 \\
(15800 \text { to } \\
20900)\end{array}$ & $\begin{array}{l}17100 \\
(14800 \text { to } \\
19700)\end{array}$ & $\begin{array}{l}15800 \\
(13600 \text { to } \\
18200)\end{array}$ & $\begin{array}{l}17500 \\
(15100 \text { to } \\
20100)\end{array}$ & $\begin{array}{l}17400 \\
(15000 \text { to } \\
20000)\end{array}$ & $\begin{array}{l}15300 \\
(13200 \text { to } \\
17600)\end{array}$ & $\begin{array}{l}15600 \\
(13500 \text { to } \\
17900)\end{array}$ & $\begin{array}{l}15800 \\
(13700 \text { to } \\
18100)\end{array}$ \\
\hline $\begin{array}{l}\text { Physical } \\
\text { education }\end{array}$ & $\begin{array}{l}6300 \\
(4900 \text { to } \\
7800)\end{array}$ & $\begin{array}{l}5700 \\
(4400 \text { to } \\
7200)\end{array}$ & $\begin{array}{l}6000 \\
(4600 \text { to } \\
7600)\end{array}$ & $\begin{array}{l}6300 \\
(4900 \text { to } \\
7900)\end{array}$ & $\begin{array}{l}5900 \\
(4600 \text { to } \\
7500)\end{array}$ & $\begin{array}{l}6400 \\
(5000 \text { to } \\
8000)\end{array}$ & $\begin{array}{l}6000 \\
(4600 \text { to } \\
7500)\end{array}$ & $\begin{array}{l}6100 \\
(4800 \text { to } \\
7600)\end{array}$ & $\begin{array}{l}5900 \\
(4600 \text { to } \\
7400)\end{array}$ & $\begin{array}{l}5700 \\
(4400 \text { to } \\
7100)\end{array}$ \\
\hline $\begin{array}{l}\text { Horse } \\
\text { riding }\end{array}$ & $\begin{array}{l}4300 \\
(3100 \text { to } \\
5600)\end{array}$ & $\begin{array}{l}4000 \\
(2900 \text { to } \\
5200)\end{array}$ & $\begin{array}{l}4700 \\
(3500 \text { to } \\
6100)\end{array}$ & $\begin{array}{l}4400 \\
(3200 \text { to } \\
5800)\end{array}$ & $\begin{array}{l}3600 \\
(2600 \text { to } \\
4800)\end{array}$ & $\begin{array}{l}3900 \\
(2800 \text { to } \\
5200)\end{array}$ & $\begin{array}{l}3900 \\
(2800 \text { to } \\
5200)\end{array}$ & $\begin{array}{l}3800 \\
(2800 \text { to } \\
5000)\end{array}$ & $\begin{array}{l}3400 \\
(2500 \text { to } \\
4500)\end{array}$ & $\begin{array}{l}3400 \\
(2400 \text { to } \\
4500)\end{array}$ \\
\hline Ice-skating & $\begin{array}{l}9100 \\
\text { (7400 to } \\
7411000)\end{array}$ & $\begin{array}{l}4700 \\
(3500 \text { to } \\
6000)\end{array}$ & $\begin{array}{l}1100 \\
(500 \text { to } \\
1800)\end{array}$ & $\begin{array}{l}8500 \\
(6800 \text { to } \\
6810300)\end{array}$ & $\begin{array}{l}3200 \\
(2200 \text { to } \\
4400)\end{array}$ & $\begin{array}{l}1400 \\
(800 \text { to } \\
2100)\end{array}$ & $\begin{array}{l}1100 \\
(500 \text { to } \\
1800)\end{array}$ & $\begin{array}{l}1000 \\
(500 \text { to } \\
1600)\end{array}$ & $\begin{array}{l}1900 \\
(1200 \text { to } \\
2800)\end{array}$ & $\begin{array}{l}3200 \\
(2300 \text { to } \\
4300)\end{array}$ \\
\hline $\begin{array}{l}\text { Road cycle } \\
\text { racing }\end{array}$ & $\begin{array}{l}1100 \\
(600 \text { to } \\
1800)\end{array}$ & $\begin{array}{l}1100 \\
(600 \text { to } \\
1800)\end{array}$ & $\begin{array}{l}2200 \\
(1400 \text { to } \\
3200)\end{array}$ & $\begin{array}{l}2300 \\
(1500 \text { to } \\
3300)\end{array}$ & $\begin{array}{l}2200 \\
(1400 \text { to } \\
3200)\end{array}$ & $\begin{array}{l}3200 \\
(2200 \text { to } \\
4400)\end{array}$ & $\begin{array}{l}2900 \\
(2000 \text { to } \\
4000)\end{array}$ & $\begin{array}{l}2700 \\
(1900 \text { to } \\
3800)\end{array}$ & $\begin{array}{l}2900 \\
(2000 \text { to } \\
3900)\end{array}$ & $\begin{array}{l}3400 \\
(2500 \text { to } \\
4500)\end{array}$ \\
\hline $\begin{array}{l}\text { Inline/roller } \\
\text { skating }\end{array}$ & $\begin{array}{l}2200 \\
(1400 \text { to } \\
3200)\end{array}$ & $\begin{array}{l}2500 \\
(1600 \text { to } \\
3500)\end{array}$ & $\begin{array}{l}2300 \\
(1500 \text { to } \\
3300)\end{array}$ & $\begin{array}{l}2000 \\
(1200 \text { to } \\
2900)\end{array}$ & $\begin{array}{l}1800 \\
(1100 \text { to } \\
2700)\end{array}$ & $\begin{array}{l}2100 \\
(1300 \text { to } \\
3000)\end{array}$ & $\begin{array}{l}1700 \\
(1000 \text { to } \\
2600)\end{array}$ & $\begin{array}{l}2000 \\
(1200 \text { to } \\
2800)\end{array}$ & $\begin{array}{l}1500 \\
(900 \text { to } \\
2200)\end{array}$ & $\begin{array}{l}1500 \\
(900 \text { to } \\
2300)\end{array}$ \\
\hline $\begin{array}{l}\text { Motorcycle } \\
\text { racing }\end{array}$ & $\begin{array}{l}1900 \\
(1200 \text { to } \\
2800)\end{array}$ & $\begin{array}{l}1500 \\
(900 \text { to } \\
2300)\end{array}$ & $\begin{array}{l}2000 \\
(1200 \text { to } \\
2900)\end{array}$ & $\begin{array}{l}1800 \\
(1100 \text { to } \\
2700)\end{array}$ & $\begin{array}{l}1800 \\
(1100 \text { to } \\
2700)\end{array}$ & $\begin{array}{l}1400 \\
(800 \text { to } \\
2200)\end{array}$ & $\begin{array}{l}1400 \\
(800 \text { to } \\
2200)\end{array}$ & $\begin{array}{l}1200 \\
(700 \text { to } \\
1900)\end{array}$ & $\begin{array}{l}1400 \\
(900 \text { to } \\
2200)\end{array}$ & $\begin{array}{l}1700 \\
(1100 \text { to } \\
2500)\end{array}$ \\
\hline $\begin{array}{l}\text { Field } \\
\text { hockey }\end{array}$ & $\begin{array}{l}2000 \\
(1200 \text { to } \\
2900)\end{array}$ & $\begin{array}{l}1400 \\
(800 \text { to } \\
2100)\end{array}$ & $\begin{array}{l}1500 \\
(900 \text { to } \\
2400)\end{array}$ & $\begin{array}{l}1400 \\
(800 \text { to } \\
2200)\end{array}$ & $\begin{array}{l}1500 \\
(900 \text { to } \\
2300)\end{array}$ & $\begin{array}{l}1600 \\
(1000 \text { to } \\
2500)\end{array}$ & $\begin{array}{l}1500 \\
(900 \text { to } \\
2300)\end{array}$ & $\begin{array}{l}1500 \\
(900 \text { to } \\
2300)\end{array}$ & $\begin{array}{l}1300 \\
(700 \text { to } \\
2000)\end{array}$ & $\begin{array}{l}1600 \\
(1000 \text { to } \\
2400)\end{array}$ \\
\hline $\begin{array}{l}\text { Mountain } \\
\text { bike racing }\end{array}$ & $\begin{array}{l}1100 \\
(600 \text { to } \\
1800)\end{array}$ & $\begin{array}{l}1000 \\
(500 \text { to } \\
1700)\end{array}$ & $\begin{array}{l}1300 \\
(700 \text { to } \\
2100)\end{array}$ & $\begin{array}{l}1500 \\
(900 \text { to } \\
2300)\end{array}$ & $\begin{array}{l}1300 \\
(700 \text { to } \\
2100)\end{array}$ & $\begin{array}{l}1700 \\
(1000 \text { to } \\
2500)\end{array}$ & $\begin{array}{l}1700 \\
(1000 \text { to } \\
2500)\end{array}$ & $\begin{array}{l}1700 \\
(1000 \text { to } \\
2500)\end{array}$ & $\begin{array}{l}1700 \\
(1000 \text { to } \\
2500)\end{array}$ & $\begin{array}{l}2200 \\
(1400 \text { to } \\
3100)\end{array}$ \\
\hline Gymnastics & $\begin{array}{l}1200 \\
(700 \text { to } \\
2000)\end{array}$ & $\begin{array}{l}1500 \\
(900 \text { to } \\
2300)\end{array}$ & $\begin{array}{l}1400 \\
(800 \text { to } \\
2200)\end{array}$ & $\begin{array}{l}1600 \\
(900 \text { to } \\
2400)\end{array}$ & $\begin{array}{l}1200 \\
(700 \text { to } \\
2000)\end{array}$ & $\begin{array}{l}1300 \\
(700 \text { to } \\
2000)\end{array}$ & $\begin{array}{l}1200 \\
(700 \text { to } \\
2000)\end{array}$ & $\begin{array}{l}1300 \\
(700 \text { to } \\
2000)\end{array}$ & $\begin{array}{l}1300 \\
(800 \text { to } \\
2000)\end{array}$ & $\begin{array}{l}1200 \\
(700 \text { to } \\
1900)\end{array}$ \\
\hline
\end{tabular}

\section{Interpretation of results}

The reduction in severe sports-related ED visits could be explained by new policies that have been adopted in the Netherlands aimed at improving the efficiency of emergency care. The number of individuals participating in sports on a weekly basis has slightly increased in the Netherlands over the years, but significant differences exist across sports activities. ${ }^{24}$ 

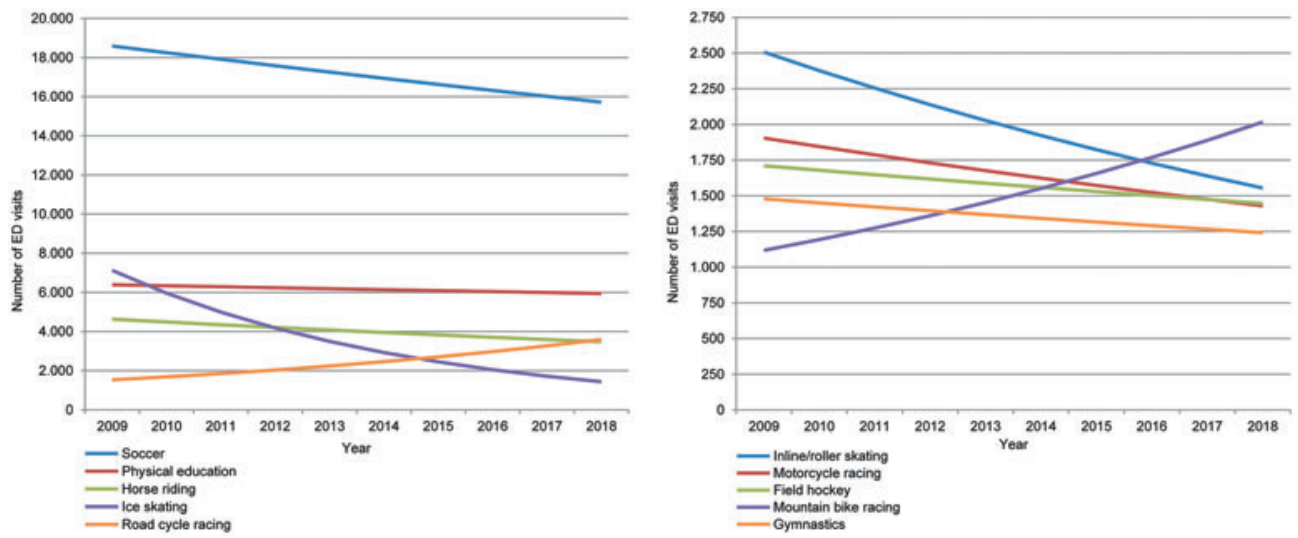

Figure 2 Time trends of severe sports-related emergency department visits in the Netherlands (2009-2018), by sports activity.

Table 3 Absolute number and 95\% Cl of severe sports-related emergency department visits in the Netherlands (2009-2018), by injury diagnosis $(1-10)$

\begin{tabular}{|c|c|c|c|c|c|c|c|c|c|c|}
\hline & 2009 & 2010 & 2011 & 2012 & 2013 & 2014 & 2015 & 2016 & 2017 & 2018 \\
\hline $\begin{array}{l}\text { Fractured } \\
\text { wrist }\end{array}$ & $\begin{array}{l}16700 \\
(14400 \text { to } \\
19200)\end{array}$ & $\begin{array}{l}15300 \\
(13200 \text { to } \\
17700)\end{array}$ & $\begin{array}{l}12800 \\
(10700 \text { to } \\
15100)\end{array}$ & $\begin{array}{l}16100 \\
(13800 \text { to } \\
18600)\end{array}$ & $\begin{array}{l}13000 \\
(11000 \text { to } \\
15300)\end{array}$ & $\begin{array}{l}13900 \\
(11800 \text { to } \\
16200)\end{array}$ & $\begin{array}{l}13200 \\
(11100 \text { to } \\
15400)\end{array}$ & $\begin{array}{l}13700 \\
(11700 \text { to } \\
15900)\end{array}$ & $\begin{array}{l}13300 \\
(11300 \text { to } \\
15400)\end{array}$ & $\begin{array}{l}14800 \\
(12800 \text { to } \\
17100)\end{array}$ \\
\hline $\begin{array}{l}\text { Fractured } \\
\text { collarbone/ } \\
\text { shoulder }\end{array}$ & $\begin{array}{l}5100 \\
(3900 \text { to } \\
6500)\end{array}$ & $\begin{array}{l}4800 \\
(3600 \text { to } \\
6200)\end{array}$ & $\begin{array}{l}5100 \\
(3800 \text { to } \\
6600)\end{array}$ & $\begin{array}{l}5600 \\
(4300 \text { to } \\
7100)\end{array}$ & $\begin{array}{l}5300 \\
(4000 \text { to } \\
6700)\end{array}$ & $\begin{array}{l}6100 \\
(4700 \text { to } \\
7600)\end{array}$ & $\begin{array}{l}5600 \\
(4300 \text { to } \\
7100)\end{array}$ & $\begin{array}{l}5500 \\
(4300 \text { to } \\
7000)\end{array}$ & $\begin{array}{l}5200 \\
(4000 \text { to } \\
6600)\end{array}$ & $\begin{array}{l}5800 \\
(4600 \text { to } \\
7200)\end{array}$ \\
\hline $\begin{array}{l}\text { Fractured } \\
\text { ankle }\end{array}$ & $\begin{array}{l}5300 \\
(4100 \text { to } \\
6800)\end{array}$ & $\begin{array}{l}4500 \\
(3400 \text { to } \\
5800)\end{array}$ & $\begin{array}{l}5200 \\
(3900 \text { to } \\
6600)\end{array}$ & $\begin{array}{l}5400 \\
(4100 \text { to } \\
6900)\end{array}$ & $\begin{array}{l}5000 \\
(3700 \text { to } \\
6400)\end{array}$ & $\begin{array}{l}4900 \\
(3700 \text { to } \\
6300)\end{array}$ & $\begin{array}{l}5200 \\
(3900 \text { to } \\
6600)\end{array}$ & $\begin{array}{l}4800 \\
(3600 \text { to } \\
6100)\end{array}$ & $\begin{array}{l}4800 \\
(3700 \text { to } \\
6100)\end{array}$ & $\begin{array}{l}5000 \\
(3800 \text { to } \\
6300)\end{array}$ \\
\hline $\begin{array}{l}\text { Fractured } \\
\text { hand }\end{array}$ & $\begin{array}{l}4800 \\
(3600 \text { to } \\
6100)\end{array}$ & $\begin{array}{l}4000 \\
(3000 \text { to } \\
5300)\end{array}$ & $\begin{array}{l}4600 \\
(3400 \text { to } \\
6000)\end{array}$ & $\begin{array}{l}4100 \\
(3000 \text { to } \\
5500)\end{array}$ & $\begin{array}{l}4000 \\
(2900 \text { to } \\
5300)\end{array}$ & $\begin{array}{l}3900 \\
(2800 \text { to } \\
5100)\end{array}$ & $\begin{array}{l}3700 \\
(2600 \text { to } \\
4900)\end{array}$ & $\begin{array}{l}2800 \\
(1900 \text { to } \\
3800)\end{array}$ & $\begin{array}{l}3100 \\
(2200 \text { to } \\
4100)\end{array}$ & $\begin{array}{l}3400 \\
(2500 \text { to } \\
4500)\end{array}$ \\
\hline $\begin{array}{l}\text { Knee } \\
\text { distortion }\end{array}$ & $\begin{array}{l}5200 \\
(3900 \text { to } \\
6600)\end{array}$ & $\begin{array}{l}4800 \\
(3600 \text { to } \\
6200)\end{array}$ & $\begin{array}{l}4300 \\
(3100 \text { to } \\
5600)\end{array}$ & $\begin{array}{l}3800 \\
(2700 \text { to } \\
5000)\end{array}$ & $\begin{array}{l}2800 \\
(1900 \text { to } \\
3900)\end{array}$ & $\begin{array}{l}2800 \\
(1900 \text { to } \\
3900)\end{array}$ & $\begin{array}{l}2600 \\
(1700 \text { to } \\
3600)\end{array}$ & $\begin{array}{l}2300 \\
(1500 \text { to } \\
3300)\end{array}$ & $\begin{array}{l}1900 \\
(1200 \text { to } \\
2800)\end{array}$ & $\begin{array}{l}2200 \\
(1500 \text { to } \\
3100)\end{array}$ \\
\hline $\begin{array}{l}\text { Fractured } \\
\text { foot }\end{array}$ & $\begin{array}{l}3400 \\
(2400 \text { to } \\
4500)\end{array}$ & $\begin{array}{l}3000 \\
(2100 \text { to } \\
4100)\end{array}$ & $\begin{array}{l}3500 \\
(2500 \text { to } \\
4700)\end{array}$ & $\begin{array}{l}3500 \\
(2400 \text { to } \\
4700)\end{array}$ & $\begin{array}{l}3400 \\
(2400 \text { to } \\
4500)\end{array}$ & $\begin{array}{l}3000 \\
(2100 \text { to } \\
4100)\end{array}$ & $\begin{array}{l}3000 \\
(2100 \text { to } \\
4200)\end{array}$ & $\begin{array}{l}2600 \\
(1800 \text { to } \\
3600)\end{array}$ & $\begin{array}{l}3500 \\
(2500 \text { to } \\
4600)\end{array}$ & $\begin{array}{l}2900 \\
(2000 \text { to } \\
3900)\end{array}$ \\
\hline $\begin{array}{l}\text { Fractured } \\
\text { forearm }\end{array}$ & $\begin{array}{l}3100 \\
(2200 \text { to } \\
4300)\end{array}$ & $\begin{array}{l}3300 \\
(2400 \text { to } \\
4500)\end{array}$ & $\begin{array}{l}3700 \\
(2600 \text { to } \\
5000)\end{array}$ & $\begin{array}{l}3600 \\
(2600 \text { to } \\
4800)\end{array}$ & $\begin{array}{l}2400 \\
(1600 \text { to } \\
3400)\end{array}$ & $\begin{array}{l}3300 \\
(2300 \text { to } \\
4400)\end{array}$ & $\begin{array}{l}2900 \\
(2000 \text { to } \\
4000)\end{array}$ & $\begin{array}{l}2800 \\
(1900 \text { to } \\
3800)\end{array}$ & $\begin{array}{l}2700 \\
(1900 \text { to } \\
3700)\end{array}$ & $\begin{array}{l}2900 \\
(2000 \text { to } \\
3900)\end{array}$ \\
\hline $\begin{array}{l}\text { Mild } \\
\text { traumatic } \\
\text { brain injury }\end{array}$ & $\begin{array}{l}3500 \\
(2500 \text { to } \\
4600)\end{array}$ & $\begin{array}{l}2900 \\
(2000 \text { to } \\
3900)\end{array}$ & $\begin{array}{l}2600 \\
(1700 \text { to } \\
3700)\end{array}$ & $\begin{array}{l}3300 \\
(2300 \text { to } \\
4500)\end{array}$ & $\begin{array}{l}2600 \\
(1700 \text { to } \\
3600)\end{array}$ & $\begin{array}{l}2600 \\
(1700 \text { to } \\
3600)\end{array}$ & $\begin{array}{l}3200 \\
(2200 \text { to } \\
4300)\end{array}$ & $\begin{array}{l}3100 \\
(2200 \text { to } \\
4200)\end{array}$ & $\begin{array}{l}2900 \\
(2000 \text { to } \\
3900)\end{array}$ & $\begin{array}{l}3400 \\
(2500 \text { to } \\
4500)\end{array}$ \\
\hline $\begin{array}{l}\text { Fractured } \\
\text { elbow }\end{array}$ & $\begin{array}{l}3100 \\
(2100 \text { to } \\
4200)\end{array}$ & $\begin{array}{l}2800 \\
(1900 \text { to } \\
3800)\end{array}$ & $\begin{array}{l}2700 \\
(1800 \text { to } \\
3700)\end{array}$ & $\begin{array}{l}2700 \\
(1800 \text { to } \\
3800)\end{array}$ & $\begin{array}{l}2500 \\
(1700 \text { to } \\
3600)\end{array}$ & $\begin{array}{l}2600 \\
(1800 \text { to } \\
3700)\end{array}$ & $\begin{array}{l}2600 \\
(1700 \text { to } \\
3700)\end{array}$ & $\begin{array}{l}2800 \\
(1900 \text { to } \\
3800)\end{array}$ & $\begin{array}{l}2400 \\
(1600 \text { to } \\
3400)\end{array}$ & $\begin{array}{l}2700 \\
(1900 \text { to } \\
3700)\end{array}$ \\
\hline $\begin{array}{l}\text { Fractured } \\
\text { lower leg }\end{array}$ & $\begin{array}{l}2300 \\
(1500 \text { to } \\
3300)\end{array}$ & $\begin{array}{l}2100 \\
(1300 \text { to } \\
3000)\end{array}$ & $\begin{array}{l}2100 \\
(1300 \text { to } \\
3100)\end{array}$ & $\begin{array}{l}2000 \\
(1300 \text { to } \\
3000)\end{array}$ & $\begin{array}{l}1900 \\
(1100 \text { to } \\
2800)\end{array}$ & $\begin{array}{l}2000 \\
(1200 \text { to } \\
2900)\end{array}$ & $\begin{array}{l}1700 \\
(1000 \text { to } \\
2600)\end{array}$ & $\begin{array}{l}1500 \\
(900 \text { to } \\
2300)\end{array}$ & $\begin{array}{l}1500 \\
(900 \text { to } \\
2300)\end{array}$ & $\begin{array}{l}1500 \\
(900 \text { to } \\
2300)\end{array}$ \\
\hline
\end{tabular}

Therefore, this cannot be an explanation for the general reduction in severe sports-related ED visits. Interestingly, when the trends in severe sports-related ED visits are compared with all severe ED visits or with other specific ED visits in the Netherlands, differences become evident. Namely, the number of all severe ED visits and severe work-related ED visits has stayed the same between 2009 and $2018 .^{18}$ In addition, the number of severe traffic-related ED visits has increased over time. 

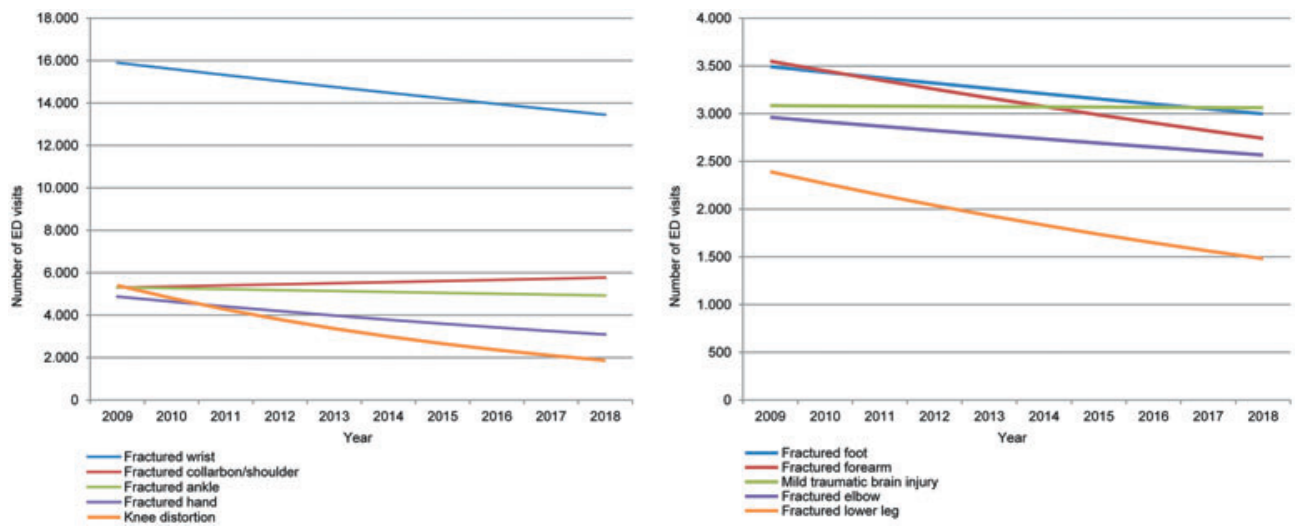

Figure 3 Time trends of severe sports-related emergency department visits in the Netherlands (2009-2018), by injury diagnosis.

The current study shows a decreasing trend of ED visits over time in soccer, ice-skating and in inline/roller skating. The decreasing trend in soccer could be explained by mandating the use of shin guards, resulting in significant decreases in lower leg fractures. ${ }^{25}$ In addition, the decreasing trend in ice-skating could be explained by milder winters, resulting in fewer individuals ice-skating outside.

In contrast, ED visits for road cycle racing and mountain bike racing increased between 2009 and 2018. One possibility for the increased ED visits could be that exposure hours of road cycle racing or mountain bike racing have changed in the past decade. A national questionnaire on accidents and exercise among Dutch inhabitants -between 2009 and 2014-found that exposure hours slightly increased for road cycle racing but stayed the same for mountain bike racing. ${ }^{26}$ However, no information about exposure hours of these sports is available for 2015 through 2018.

\section{Strengths and limitations}

A strength of the current study is the use of the DISS data set. This data set is composed of a representative sample of nationwide sports-related ED visits. Furthermore, the current study extensively describes the number of severe sportsrelated ED visits on different age groups, gender, sports activities and injury diagnoses over a period of 10 years. A limitation is that this study does not provide a complete picture of nationwide sports injuries, as only severe sportsrelated ED visits were included in the analyses. Including low-risk activities (ie, minor injuries) in the analyses could give a better overview of sports injuries, aimed to look at preventative efforts. Another limitation of the study is that injury data are not corrected for exposure hours as this information is unavailable in the Netherlands. In the current study, a correction was made for changes in population composition between 2009 and 2018.

\section{CONCLUSION}

Between 2009 and 2018, the number of severe sportsrelated ED visits decreased considerably in the Netherlands across most age groups and sports activities. In contrast, the number of ED visits increased in road cycle racing and mountain bike racing. The results of the current study could act as a guide for the development of specific injury prevention policies, especially for road cycle racing and mountain bike racing. Future research should try to find out why these increasing trends are present. Determining the trends in exposure hours is essential, as well as evaluating injury prevention programmes specifically for road cycle racing and mountain bike racing.

\section{Twitter Evert Verhagen @evertverhagen.}

Acknowledgements The authors thank the Dutch hospitals for their collection of the data that are registered in the Dutch Injury Surveillance System.

Contributors BO: concept, methodology, analysis, writing, editing paper. EK, HV: concept, methodology, editing paper. CS: methodology, analysis, editing paper. VG, EV: methodology, editing paper.

Funding The authors have not declared a specific grant for this research from any funding agency in the public, commercial or not-for-profit sectors.

Competing interests None declared.

Ethics approval Not required.

Provenance and peer review Not commissioned; externally peer reviewed.

Data availability statement № data are available.

Supplemental material This content has been supplied by the author(s). It has not been vetted by BMJ Publishing Group Limited (BMJ) and may not have been peerreviewed. Any opinions or recommendations discussed are solely those of the author(s) and are not endorsed by BMJ. BMJ disclaims all liability and responsibility arising from any reliance placed on the content. Where the content includes any translated material, BMJ does not warrant the accuracy and reliability of the translations (including but not limited to local regulations, clinical guidelines, terminology, drug names and drug dosages), and is not responsible for any error and/or omissions arising from translation and adaptation or otherwise.

Open access This is an open access article distributed in accordance with the Creative Commons Attribution Non Commercial (CC BY-NC 4.0) license, which permits others to distribute, remix, adapt, build upon this work non-commercially, and license their derivative works on different terms, provided the original work is properly cited, appropriate credit is given, any changes made indicated, and the use is non-commercial. See: http://creativecommons.org/licenses/by-nc/4.0/

\section{ORCID iDs}

Branko F Olij http://orcid.org/0000-0002-7556-3786

Evert Verhagen http://orcid.org/0000-0001-9227-8234

\section{REFERENCES}

1 Warburton DER, Bredin SSD. Health benefits of physical activity: a systematic review of current systematic reviews. Curr Opin Cardiol 2017;32:541-56. 
2 Field AE, Tepolt FA, Yang DS, et al. Injury risk associated with sports specialization and activity volume in youth. Orthop $J$ Sport Med 2019;7:2325967119870124.

3 Verhagen E. The cost of sports injuries. J Sci Med Sport 2010;13:e40.

4 Forsdyke D, Smith A, Jones M, et al. Psychosocial factors associated with outcomes of sport injury rehabilitation in competitive athletes: a mixed methods studies systematic review. Br J Sports Med 2016;50:123-30.

5 Finch CF. Getting sports injury prevention on to public health agendas addressing the shortfalls in current information sources. Br J Sport Med 2012;46:70-4.

6 Bayt DR, Bell TM. Trends in paediatric sports-related injuries presenting to US emergency departments, 2001-2013. Inj Prev 2016;22:361-4

7 Finch CF, Kemp JL, Clapperton AJ. The incidence and burden of hospital-treated sports-related injury in people aged 15+ years in Victoria, Australia, 2004-2010: A future epidemic of osteoarthritis? Osteoarthr Cartil 2015;23:1138-43.

8 Toet H, Blatter B, Panneman M, et al. Dutch Injury Surveillance System: methods and applications (in Dutch). Amsterdam, The Netherlands: VeiligheidNL, 2019.

9 Pannier J. Bewegingsopvoeding in Een Gezondheidsperspectief Sportmedische Advisering Voor Bewegingsopvoeding Op School (in Dutch). Amersfoort (the Netherlands), 1988.

10 Gaakeer MI, van den Brand CL, Gips E, et al. National developments in emergency departments in the Netherlands: numbers and origins of patients in the period from 2012 to 2015 (in Dutch). Ned Tijdschr Geneeskd 2016;160:D970.

11 Gommer AM, Gijsen R. The validity of the estimates of the national number of visits to emergency departments on the basis of data from the injury surveillance system LIS (in Dutch). Bilthoven, The Netherlands: RIVM, 2016.

12 Meerding WJ, Polinder S, Lyons RA, et al. How adequate are emergency department home and leisure injury surveillance systems for cross-country comparisons in Europe. Int $J$ Inj Control Saf Promot 2010;17:13-22.

13 Panneman M, Blatter B. Dutch injury surveillance system representative for all emergency departments in the Netherlands? (In Dutch). Amsterdam, The Netherlands: VeiligheidNL, 2016.
14 Banning R, Camstra A, Knottnerus P. Statistics methods 201207 sampling theory: sampling design and estimation methods. Heerlen, The Netherlands: Statistics Netherlands, 2012.

15 Association for the Advancement of Automotive Medicine. Abbreviated injury scale: 2015 rision. 6th ed. Chicago, USA, 2018.

16 Mannaerts GHH, Sawor JH, Menovsky T, et al. De betrouwbaarheid van de registratie van polytrauma-patiënten (in Dutch). Ned Tijdschr Geneeskd 1994;138:2290-3.

17 World Health Organization. International classification of diseases. Published 2010. Available http://www.who.int/classifications/icd (accessed 24 Mar 2020).

18 Stam C, Blatter B. Letsel 2018: Kerncijfers LIS (in Dutch). Amsterdam, The Netherlands: VeiligheidNL, 2019.

19 Israëls A. Methods of standardisation (in Dutch). The Hague/Heerlen, The Netherlands: Statistics Netherlands, 2013.

20 Statistics Netherlands. Dutch population (in Dutch). Published 2019. Available http://www.cbs.nl/en-gb/society/population (accessed 24 Mar 2020)

21 Tharanga Fernando D, Berecki-Gisolf J, Finch C. Sports injuries in Victoria, 2012-13 to 2014-15: evidence from emergency department records. Med J Aust 2018;208:255-60.

22 Röding F, Lindkvist M, Bergström U, et al. Epidemiologic patterns of injuries treated at the emergency department of a Swedish medical center. Inj Epidemiol 2015;2:1-8.

23 Andrew NE, Gabbe BJ, Wolfe R, et al. Trends in sport and active recreation injuries resulting in major trauma or death in adults in Victoria, Australia, 2001-2007. Injury 2012;43:1527-33.

24 Statistics Netherlands. Sportdeelname wekelijks - Het aandeel van de Nederlandse bevolking van 4 jaar en ouder dat één keer per week of vaker sport (in Dutch). Available https://www.sportenbewegenincij fers.nl/kernindicatoren/sportdeelname-wekelijks (accessed 24 Mar 2020)

25 Vriend I, Valkenberg H, Schoots W, et al. Shinguards effective in preventing lower leg injuries in football: population-based trend analyses over 25 years. J Sci Med Sport 2015;18:518-22.

26 VeiligheidNL. Accidents and exercise in the Netherlands (in Dutch). Amsterdam, The Netherlands, 2015. 